\title{
The Molecular and Pharmacological Properties of Muscarinic Cholinergic Receptors Expressed by Rat Sweat Glands Are Unaltered by Denervation
}

\author{
Michael P. Grant, ${ }^{1,2}$ Story C. Landis, ${ }^{2}$ and Ruth E. Siegel ${ }^{1}$ \\ Departments of ${ }^{2}$ Pharmacology and ${ }^{2}$ Neurosciences, Case Western Reserve University, School of Medicine, Cleveland, \\ Ohio 44106
}

Previous studies have indicated that denervation of adult rodent sweat glands results in the loss of secretory responsiveness to muscarinic agonists. To elucidate the molecular basis of this loss, we have characterized the muscarinic cholinergic receptor present in adult rat sweat glands and examined the effects of cholinergic denervation on its properties and expression. When homogenates of gland-rich tissue from adult animals were assayed with [ $\mathrm{N}$-methyl-3 $\mathrm{H}$ ]scopolamine, a high-affinity muscarinic antagonist, the concentration of muscarinic receptors was $301 \mathrm{fmol} / \mathrm{mg}$ protein and the affinity was $131 \mathrm{pm}$. Autoradiographic analysis demonstrated that ligand binding sites were detectable only on glands. In competition studies with well-characterized muscarinic agents, the receptor exhibited typical muscarinic pharmacology. Further investigation with the selective muscarinic antagonists 4 -diphenylacetoxy- $N$-methylpiperidine methiodide, pirenzepine, and AF DX-116 revealed that the sweat gland receptor belongs to the $M_{2}$ glandular pharmacological subtype. In situ hybridization histochemistry with receptor subtype-specific oligonucleotide probes indicated that rat sweat glands express the $\mathrm{m} 3$ molecular receptor subtype. Seven days after sciatic nerve transection, when denervated glands were compared to those on the contralateral unoperated side, there was no significant difference either in the concentration or affinity of muscarinic binding sites or in receptor density or distribution. Furthermore, the molecular subtype and the level of its expression were unchanged. Thus, it appears that muscarinic binding sites and $m 3$ receptor mRNA are present in denervated sweat glands that are unresponsive to muscarinic stimulation. These results suggest that the regulation of responsiveness occurs at a point distal to the expression of muscarinic receptors.

\footnotetext{
Received Mar. 29, 1991; revised June 19, 1991; accepted June 27, 1991.

We thank Drs. Marshall Snavely and James Unnerstall for their assistance in developing the binding assay protocol and Dr. George Dubyak for helpful discussions. We also thank Dr. Steven Jones for his assistance with data analysis and review of the manuscript. This work was supported by NIH Grant NS 23678 and NIDDK Grant P30 27651 to S.C.L. and a grant from Mathers Foundation to R.E.S. M.P.G. was supported by NIH Grant GM07382-14.

Correspondence should be addressed to Michael P. Grant, Department of Neurosciences, Case Western Reserve University, School of Medicine, 10900 Euclid Avenue, Cleveland, $\mathrm{OH} 44106-4975$.

Copyright (C) 1991 Society for Neuroscience 0270-6474/91/113763-09\$05.00/0
}

Muscarinic cholinergic receptors are a family of closely related molecular subtypes that possess distinct functional properties (reviewed by Nathanson, 1987; Bonner, 1989; Hulme et al., 1990). The heterogeneity of this receptor class was initially revealed in pharmacological studies. Based on differing affinities for the antagonist pirenzepine in competition experiments with $\left[N\right.$-methyl- $\left.{ }^{3} \mathrm{H}\right]$-scopolamine $\left(\left[{ }^{3} \mathrm{H}\right] \mathrm{NMS}\right)$, muscarinic receptors were divided into three broad pharmacological classes (designated by "M"): a high-affinity or $\mathbf{M}_{1}$ site found predominantly in brain $\left(K_{i}<10 \mathrm{~nm}\right)$ and intermediate- and low-affinity sites located predominantly in peripheral autonomic targets $\left(K_{i} \mathbf{s}=\right.$ 300 and $800-1000 \mathrm{nM}$, respectively), which have been collectively designated as $\mathbf{M}_{2}$ (Hammer et al., 1980). Parotid and lacrimal glands possess the intermediate-affinity site, while heart contains the low-affinity site (Hammer et al., 1980). The characterization of these classes was further refined following the development of two additional compounds; 4-diphenylacetoxy$N$-methylpiperidine methiodide (4-DAMP) possesses high affinity for most exocrine gland receptors and AF DX-116 possesses high affinity for the heart receptor (Barlow and Shepherd, 1986; Hammer et al., 1986). Based on these studies, the $\mathbf{M}_{2}$ receptors have been subclassified as $\mathbf{M}_{2}$ cardiac and $\mathbf{M}_{2}$ glandular (Barlow and Shepherd, 1986; Hammer et al., 1986).

Subsequent molecular cloning studies have demonstrated that in both humans and rats muscarinic receptors comprise a family of five related genes (designated by "m"), m1-m5 (Kubo et al., 1986a,b; Bonner et al., 1987, 1988; Peralta et al., 1987a,b). The mRNAs that correspond to these proteins have a heterogeneous distribution in peripheral autonomic targets and CNS (Peralta et al., 1987a; Buckley et al., 1988; Maeda et al., 1988). For each molecular subtype, competition studies performed with cell lines transfected with cDNAs encoding a single molecular subtype have yielded distinct pharmacological profiles (Peralta et al., 1987a; Akiba et al., 1988; Bonner et al., 1988; Buckley et al., 1989); for example, the $m 1$ receptor possesses high affinity for pirenzepine and low affinity for AF DX-116, while the $\mathrm{m} 2$ receptor exhibits high affinity for AF DX-116 and low affinity for pirenzepine and 4-DAMP. These two molecular subtypes, $\mathrm{ml}$ and $m 2$, are believed to correspond to the $M_{1}$ and $M_{2}$ heart pharmacological subtypes. Analysis of cell expression systems has also suggested that particular molecular subtypes are preferentially coupled to specific intracellular effectors. The $\mathrm{m} 1, \mathrm{~m} 3$, and $\mathrm{m} 5$ subtypes interact with phospholipase $\mathrm{C}$ and thus activate the phosphoinositide (PI) pathway, whereas the $\mathrm{m} 2$ and 
$\mathrm{m} 4$ receptors are coupled to inhibition of adenyl cyclase (Ashkenazi et al., 1987; Fukuda et al., 1988; Jones et al., 1988; Peralta et al., 1988). Although the diversity of this receptor family is now well established, relatively little is known about the specific distributions of the different molecular subtypes in peripheral tissues and the relationship between particular molecular subtypes and pharmacological properties in vivo.

Cholinergic denervation of peripheral targets produces diverse effects on muscarinic receptor expression. Denervation of cat iris by extirpation of the ciliary ganglion produces no change in the concentration or affinity of muscarinic receptors (Sachs et al., 1979). In contrast, parasympathectomy of rat urinary bladder produces an increase in the concentration of muscarinic receptors; a portion of this increase, however, may result from the compensatory hypertrophy that accompanies bladder denervation (Nilvebrant et al., 1986). Finally, denervation of rat parotid gland produces a decrease in the number of muscarinic receptors (Talamo et al., 1979). Since muscarinic receptors are heterogeneous and the several subtypes may be regulated differently, the varying responses to denervation could reflect differences in the molecular subtype expressed by target cells. In none of the studies to date, however, has the expression of specific molecular subtypes been examined. Therefore, it remains unclear whether the observed changes in the level of receptor expression, or lack thereof, are related to the specific target cell types or, alternatively, whether they are a function of the molecular subtype(s) expressed.

Rat eccrine sweat glands provide an interesting model system to study the expression and regulation of muscarinic receptors. In rats, sweat glands are concentrated in footpads. The innervation of rat sweat glands is sympathetic in origin but cholinergic in pharmacology; sweat secretion can be elicited by cholinergic agonists, and muscarinic cholinergic antagonists block nerveevoked sweat secretion (Stevens and Landis, 1987). ChAT and $\mathrm{AChE}$, the enzymes of synthesis and degradation of $\mathrm{ACh}$, are present in the gland innervation (Landis and Keefe, 1983; Leblanc and Landis, 1986). Previous studies have raised the possibility that muscarinic ACh receptors are downregulated following denervation. Sweat secretion in response to cholinergic agonists disappears after denervation in the rat (Hayashi and Nakagawa, 1963). Similarly, denervation of mouse sweat glands yields glands that are unresponsive to cholinergic agonists; interestingly, the glands regain responsiveness following collateral reinnervation (Kennedy and Sakuta, 1984; Kennedy et al., 1984). Thus, secretory responsiveness of rat and mouse sweat glands depends upon functional innervation. The effects of denervation on rodent sweat gland responsiveness differ from those of denervation on responsiveness of other autonomic targets. In parotid gland (Talamo et al., 1979; Ekstrom, 1980), iris (Sachs et al., 1979), and urinary bladder (Nilvebrant et al., 1986), denervation results in supersensitivity to cholinergic agonists.

To learn more about the role of innervation in the regulation of neurotransmitter receptors and responsiveness in autonomic tissues, we have examined the expression and properties of muscarinic receptors in rat sweat glands. Our studies demonstrate that sweat gland receptors display the characteristics of the muscarinic receptor defined pharmacologically as the $\mathbf{M}_{2}$ glandular subtype and they correspond to the $\mathrm{m} 3$ molecular subtype. We have investigated the expression of muscarinic receptors in denervated rat sweat glands and found that, although sweat secretion is absent, receptor properties and number are unchanged. Our results suggest that functional sympathetic cholinergic innervation plays a central role in the maintenance of secretory function at a site distinct from the receptor.

Preliminary reports of these studies have appeared previously (Grant and Landis, 1988, 1989).

\section{Materials and Methods}

Materials. Carbamylcholine, atropine sulfate, chloral hydrate, pilocarpine, oxotremorine sesquifumarate, dithiothreitol (DTT), acetic anhydride, triethanolamine, dextran sulfate, bovine serum albumin, ssDNA, and yeast $t$ RNA were obtained from Sigma (St. Louis, MO). Pirenzepine and 4-diphenylacetoxy- $N$-methylpiperidine methiodide (4-DAMP) were purchased from Research Biochemical Inc. (Natick, MA). AF DX-116 was the kind gift of Boehringer Ingelheim (Ridgefield, CT). Terminal deoxynucleotidyl transferase was obtained from Bethesda Research Labs. $\left[N\right.$-methyl- $\left.{ }^{3} \mathrm{H}\right]$-scopolamine $(85 \mathrm{Ci} / \mathrm{mmol}),{ }^{35} \mathrm{~S}$-deoxyadenosine $5^{\prime}-[\alpha$ thio]triphosphate $(1320 \mathrm{Ci} / \mathrm{mmol})$, and Formula 963 were from New England Nuclear (Boston, MA). Photographic emulsion NTB-3, D-19 developer, and fixer were from Kodak (Rochester, NY). All other reagents were obtained from Fisher and were reagent grade or better.

Animals. Litters and adult Sprague-Dawley rats were obtained from Zivic-Miller (Zelienople, PA). The sweat glands of adult rats were denervated by cutting the sciatic nerve. Rats were deeply anesthetized with chloral hydrate, the lateral aspect of the upper thigh was shaved, and the surgical area was swabbed with ethanol. A $2-3 \mathrm{~cm}$ longitudinal incision was made over the head of the humerus. The sciatic nerve was visualized by reflecting the inferior aspect of the gluteus maximus superiorly and reaching under the biceps femoris. A $1.5 \mathrm{~cm}$ segment of sciatic nerve was removed, and the wound was closed with wound clips.

Secretion assay. Sweat secretion was assayed by making a silicone elastic (Kerr Co., Romulus, MI) mold of the plantar surface of the rat footpad as described previously (Kennedy et al., 1984; Stevens and Landis, 1987). Animals were injected subcutaneously with $3 \mathrm{mg} / \mathrm{kg}$ of pilocarpine, and the impression material was applied $20 \mathrm{~min}$ later and allowed to harden. The impression material is not miscible with water; therefore, each sweat droplet forms a small pore in the mold as the material hardens. Since each pore represents the response of an individual sweat gland, the secretory response may be quantitated with a dissecting microscope.

Muscarinic receptor assay. Gland-rich tissue was collected for assay by removing footpads and carefully dissecting away the dermis and epidermis; this procedure yielded small chunks of tissue containing sweat glands, connective tissue, and fat cells. The tissue was frozen on dry ice and stored at $-70^{\circ} \mathrm{C}$. At the time of assay, the tissue chunks were suspended in ice-cold homogenization buffer containing $10 \mathrm{~mm}$ phosphatc buffer ( $\mathrm{pH} \mathrm{7.2)}, 125 \mathrm{mM} \mathrm{NaCl}, 2 \mathrm{mM} \mathrm{KCl}, 5 \mathrm{mM} \mathrm{MgCl}$, and $1 \mathrm{~mm}$ EDTA and homogenized with a Potter-Elvejhem glass-Teflon homogenizer. The suspension was filtered through a single layer of cheesecloth and then homogenized further with a Brinkmann Polytron. The crude homogenate was centrifuged at $50,000 \times g$ for $15 \mathrm{~min}$, the supernatant was discarded, and the crude membrane pellet was resuspended in homogenization buffer. This procedure was repeated twice, and the final pellet was resuspended in homogenization buffer at a protein concentration of approximately $0.2-0.4 \mathrm{mg} / \mathrm{ml}$.

The concentration and affinity of muscarinic ligand binding sites were determined using the nonselective muscarinic receptor antagonist [ $N$ methyl- $\left.{ }^{3} \mathrm{H}\right]$-scopolamine $\left(\left[{ }^{3} \mathrm{H}\right] \mathrm{NMS}\right)$. Binding assays were performed at room temperature by incubating $100 \mu \mathrm{l}$ of crude membranes $(20-40 \mu \mathrm{g}$ per assay tube) with $900 \mu \mathrm{l}$ of assay buffer (20 mM HEPES, $125 \mathrm{~mm}$ $\mathrm{NaCl}, 5 \mathrm{mM} \mathrm{MgCl}_{2}, 1 \mathrm{~mm}$ EGTA, and $1 \mathrm{~mm}$ DTT) containing [ $\left.{ }^{3} \mathrm{H}\right] \mathrm{NMS}$ $(0.025-1.2 \mathrm{nM})$ for $50 \mathrm{~min}$. Preliminary studies indicated that the specific binding was maximal after $30 \mathrm{~min}$ and linear over a protein concentration range of $20-400 \mu \mathrm{g} / \mathrm{ml}$ (data not shown). The binding assay was terminated by the addition of $5 \mathrm{ml}$ of ice-cold assay buffer. The samples were rapidly filtered over \#32 glass fiber filters (Schleicher \& Schuell, Keene, $\mathrm{NH}$ ) and washed twice with $5 \mathrm{ml}$ of ice-cold assay buffer using a Brandel cell harvester (model M-24R, Brandel, Inc., Gaithersburg, MD). Filters were transferred to scintillation vials and counted. Specific binding was defined as the number of total counts bound minus the nonspecific counts bound in the presence of $10 \mu \mathrm{M}$ atropine sulfate. Binding data were analyzed by the method of Scatchard (1949); mean $K_{d}, K_{i}$, and $B_{\max }$ were calculated with the EBDA/LIGAND program (Biosoft, Cambridge, UK). Mean control and experimental values were compared for statistical significance using the Student's $t$ test. Protein concentration was determined by the method of Lowry et al. (1951). 


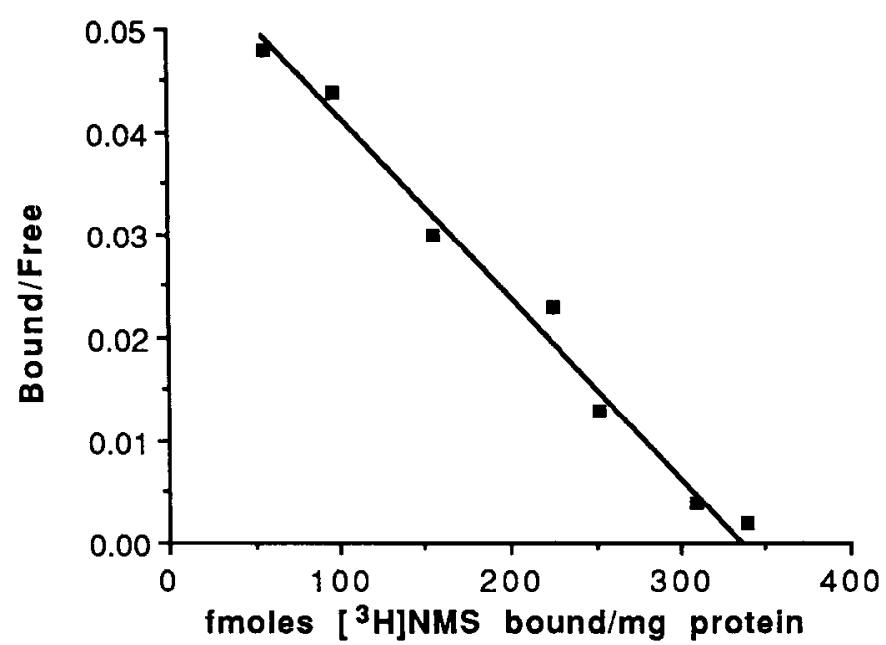

Figure 1. Equilibrium binding of $\left[{ }^{3} \mathrm{H}\right] \mathrm{NMS}$ to homogenates of rat footpad. Homogenates of rat footpad were incubated with increasing concentrations of $\left[{ }^{3} \mathrm{H}\right] \mathrm{NMS}$, and the binding data were analyzed by the Scatchard method. The data shown are representative of results obtained in five separate experiments; each point is the mean of three determinations. The calculated $K_{d}$ and $B_{\max }$ for this experiment were $135 \pm 6$ pM and $327 \pm 25 \mathrm{fmol} / \mathrm{mg}$ protein, respectively. Following EBDA/LIGAND analysis, the $K_{d}$ of the receptor was determined to be $131 \pm 6 \mathrm{pM}$, and the $B_{\max }, 301 \pm 23 \mathrm{fmol} / \mathrm{mg}$ protein $(n=5)$.

Receptor autoradiography. Light microscopic autoradiography was performed essentially as previously described (Wamsley et al., 1981; Herkenham, 1985). In brief, rats were perfused through the left ventricle with ice-cold phosphate-buffered saline (PBS; $\mathrm{pH}$ 7.2). The rear footpads were rapidly removed, mounted in OCT compound (Miles Labs Inc.), and frozen. Ten-micron sections were thaw-mounted onto untreated glass slides and stored at $-20^{\circ} \mathrm{C}$. Prior to labeling, the tissue sections were warmed to room temperature. Sections were incubated with $1 \mathrm{nM}$ [ $\left.{ }^{3} \mathrm{H}\right] \mathrm{NMS}$ in PBS for $50 \mathrm{~min}$ at room temperature, dipped in distilled water to terminate the incubation, washed twice in ice-cold PBS for 2.5 min, and finally dipped in distilled water. Nonspecific binding was assayed by processing sections under identical conditions in the presence of $10 \mu \mathrm{M}$ atropine sulfate. The tissue sections were dried and stored overnight at $4^{\circ} \mathrm{C}$ prior to application of emulsion-coated coverslips. The coverslips (No. 1, $25 \times 77 \mathrm{~mm}$; Diamond Brand, Gaithersburg, MD) were coated with a uniform layer of NTB-3 photographic emulsion diluted 1:1 with water, glued to the frosted end of the slide with Super Glue, and clamped in place. After exposures of $3-13$ weeks at $4^{\circ} \mathrm{C}$ in a desiccated chamber, the autoradiograms were developed in $\mathrm{D}-19$ at $17^{\circ} \mathrm{C}$ for $2.5 \mathrm{~min}$, washed for $15 \mathrm{sec}$ in distilled water, and fixed for $5 \mathrm{~min}$. The tissue sections were stained with $0.4 \%$ cresyl violet in water, dried overnight, and mounted with DPX (BDH Limited, Poole, UK). Secretory coils were outlined for analysis by examination of the cresyl violetstained section. Grains per area were determined over glands from control and denervated animals using an Olympus Cue-4 image analysis system. Specitic grain densities were calculated by subtracting the value of nonspecific grain density found in the presence of $10 \mu \mathrm{M}$ atropine from the total grain density. Autoradiographic exposure times were the same for the control and denervated sweat gland sections. Specific grain counts from different groups were compared for statistical significance using the Student's $t$ test.

In situ hybridization histochemistry. Frozen sections of rat footpad were cut, thaw-mounted onto gelatin-coated slides, and stored at $-80^{\circ} \mathrm{C}$. Prior to hybridization, tissue sections were warmed for $5 \mathrm{~min}$ at room temperature and then fixed for $5 \mathrm{~min}$ in $4 \%$ paraformaldehyde in 0.1 M phosphate buffer. The slides were then rinsed in PBS and processed as described previously with minor modifications (Young et al., 1986; Siegel, 1988). Slides were immersed in $0.25 \%$ acetic anhydride in 0.1 $\mathrm{M}$ triethanolamine ( $\mathrm{pH} 8.0$ ) for $10 \mathrm{~min}$. The sections were rinsed in $2 \times$ $\mathrm{SSC}(1 \times \mathrm{SSC}=0.15 \mathrm{M} \mathrm{NaCl}, 0.015 \mathrm{~m}$ sodium citrate, $\mathrm{pH} 7.0)$ and dehydrated through graded alcohols. The sections were then immersed in chloroform for $10 \mathrm{~min}$ followed by a second $10 \mathrm{~min}$ incubation in $95 \%$ ethanol and air dried. The sections were prehybridized with $50 \mu \mathrm{l}$
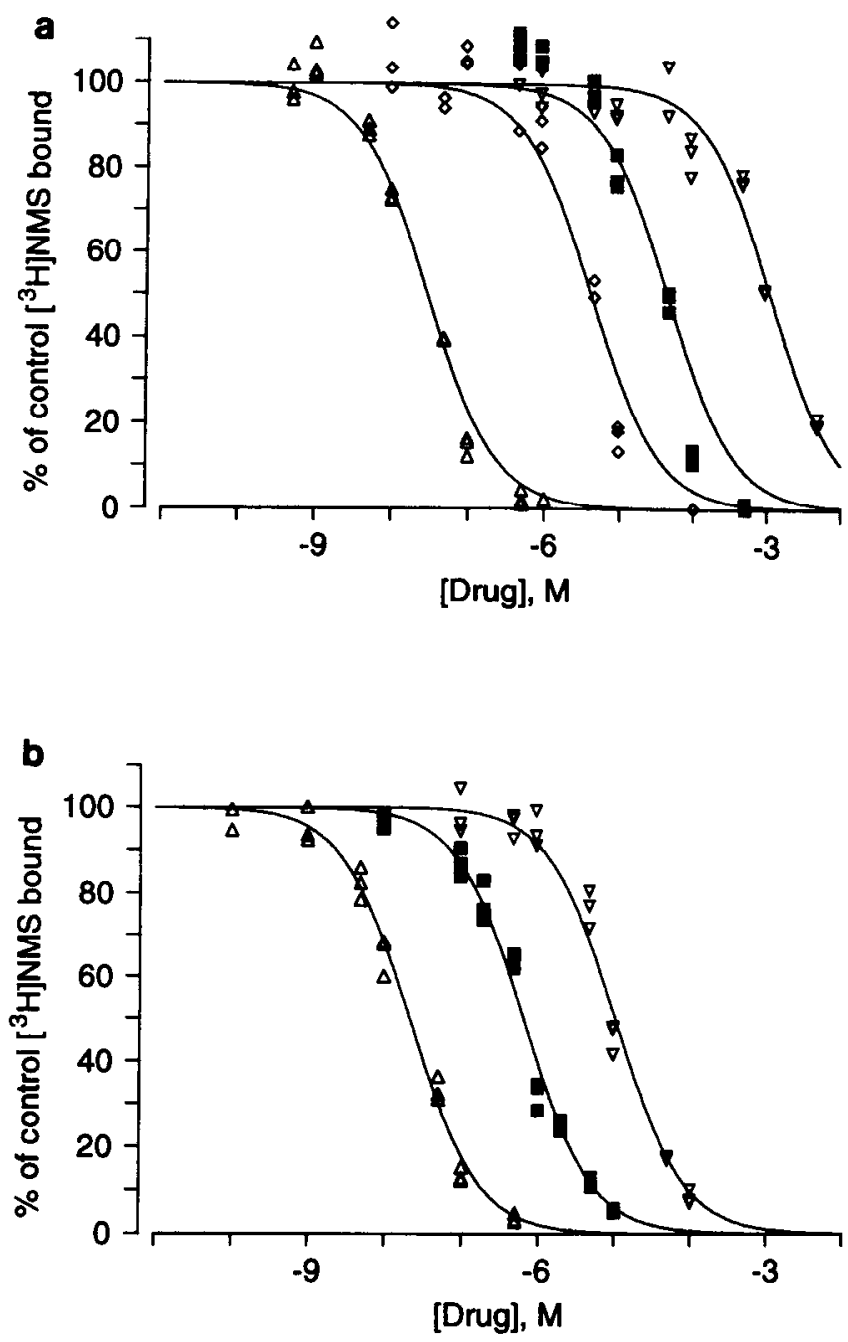

Figure 2. a, Inhibition of $\left[{ }^{3} \mathrm{H}\right] \mathrm{NMS}$ by nonselective muscarinic ligands: atropine (triangles), oxotremorine (diamonds), pilocarpine (squares), and carbachol (inverted triangles). Homogenates of rat footpad were incubated with $0.1 \mathrm{nM}\left[{ }^{3} \mathrm{H}\right] \mathrm{NMS}$ and the indicated concentration of competing ligand. The data shown are representative of results obtained in two to five separate experiments; for each concentration of competing ligand, the triplicate data points are plotted. The $\mathrm{IC}_{50}$ values for these experiments were atropine, $0.031 \mu \mathrm{M}$; oxotremorine, $4.6 \mu \mathrm{M}$; pilocarpine, $48 \mu \mathrm{M}$; and carbachol, $1100 \mu \mathrm{M}$. Competition curves were analyzed with the EBDA/LIGAND program, and the $K_{i}$ values were determined. The calculated $K_{i}$ values were atropine, $0.003 \mu \mathrm{M}$; oxotremorine, $8.8 \mu \mathrm{M}$; pilocarpine, $125 \mu \mathrm{M}$; and carbachol, $440 \mu \mathrm{M}$. $b$. Inhibition of $\left[{ }^{3} \mathrm{H}\right] \mathrm{NMS}$ binding by three subtype-selective antagonists: 4-DAMP (triangles), pirenzepine (squares), and AF DX-116 (inverted triangles). Competition curves were analyzed with the EBDA/LIGAND program, and the $K_{i}$ values were determined. The data shown are representative of results obtained in two to five separate experiments; for each concentration of competing ligand, the triplicate data points are plotted. The $\mathrm{IC}_{50}$ values for these experiments were 4-DAMP, $0.021 \mu \mathrm{M}$; pirenzepine, $0.650 \mu \mathrm{M}$; and AF DX-116, $10.5 \mu \mathrm{M}$. The calculated $K_{i}$ values were 4-DAMP, $0.020 \mu \mathrm{M}$; pirenzepine, $0.244 \mu \mathrm{M}$; and AF DX-116, $1.12 \mu \mathrm{M}$.

of hybridization buffer $(4 \times$ SSC, $50 \%$ formamide, $10 \%$ dextran sulfate, $2 \mathrm{mg} / \mathrm{ml}$ bovine serum albumin, $1 \mathrm{mg} / \mathrm{ml}$ yeast $t$ RNA, and $1 \mathrm{mg} / \mathrm{ml}$ ssDNA) for $5 \mathrm{hr}$ at room temperature. Sections were covered with Parafilm coverslips to prevent drying. Following prehybridization, the sections were incubated with $50 \mu \mathrm{l}$ of hybridization buffer containing $7.5 \times 10^{5} \mathrm{cpm}$ of ${ }^{35} \mathrm{~S}$-labeled probe and $100 \mathrm{~mm}$ DTT for $22 \mathrm{hr}$ at room temperature. After incubation, the Parafilm coverslips were floated off in $2 \times \mathrm{SSC}$, and the sections were washed four times for $15 \mathrm{~min}$ in $50 \%$ 

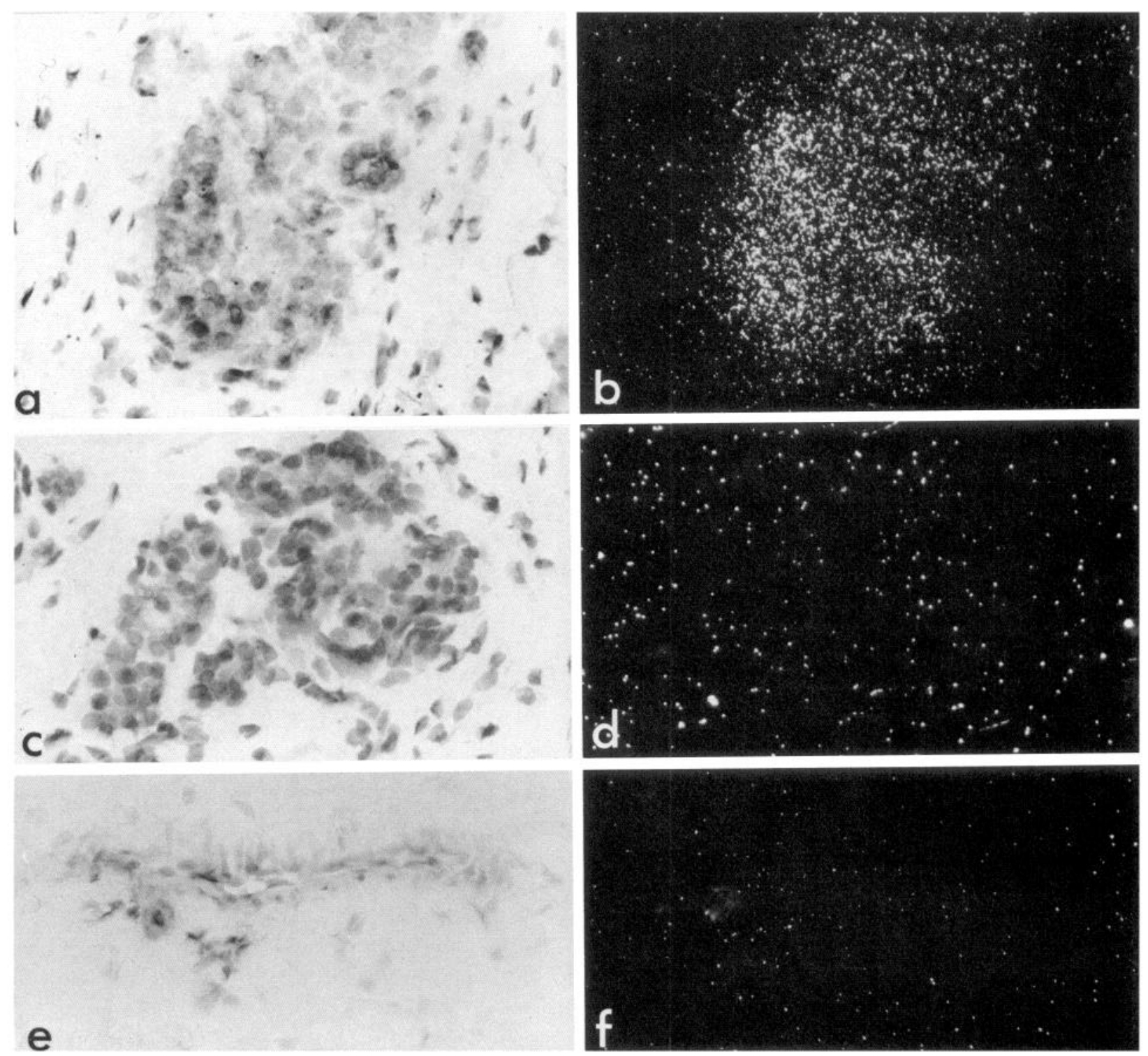

Figure 3. Autoradiograms of $\left[{ }^{3} \mathrm{H}\right] \mathrm{NMS}$ binding to sections of adult rat footpad. Ten-micron sections were incubated with $1 \mathrm{nM}\left[{ }^{3} \mathrm{H}\right] \mathrm{NMS}$ and processed for autoradiography. $a$, Bright-field view of the secretory coil of an adult rat sweat gland. $b$, In the same field as $a$ viewed in dark-field, grains are concentrated over the secretory coil. $c$ and $d$, Bright- and dark-field views of the secretory coil following binding in the presence of 10 $\mu \mathrm{M}$ atropine. Only background levels of grains were observed. $e$, Bright-field view of an arteriole in the footpad. $f$, When the same field as $e$ is examined with dark-field optics, ligand binding sites are not detectable. Autoradiograms were exposed for 12 weeks. Magnification, $315 \times$.

formamide $/ 2 \times \mathrm{SSC}$ at $42^{\circ} \mathrm{C}$ and two times for 60 min each in $1 \times \mathrm{SSC}$ at room temperature. Following these washes, the sections were dried overnight at room temperature. The slides were dipped in emulsion diluted $1: 1$ with water and exposed at $4^{\circ} \mathrm{C}$ in a desiccated chamber for 6-8 weeks. The autoradiographs were developed in D19, stained, and mounted as described above. Grain density was determined by counting the number of grains over the area of a sweat gland as described above for receptor autoradiography. The background or nonspecific grain density was determined by two methods. First, the grain density over glands hybridized with the $\mathrm{m} 2$ probe was determined; message for the $\mathrm{m} 2$ receptor in the periphery has only been found in the heart and thus should not be present in sections of footpad. Second, the density of grains in sections hybridized with the $\mathrm{m} 3$ probe was determined over areas that contained connective tissue and fat cells but not sweat glands. The background grain density determined by these methods was similar, and specific counts were determined by subtracting the background density from the total. Specific grain counts from different groups were compared for statistical significance using the Student's $t$ test.
Probes. Oligodeoxynucleotide probes were made by solid-phase synthesis on an Applied Biosystem DNA synthesizer (courtesy of Dr. Bruce Levison, Case Western Reserve University, School of Medicine). Probes $45(\mathrm{~m} 4)$ or $48(\mathrm{ml}, 2,3,5)$ bases in length were made complementary to the region of the mRNA encoding the N-terminal domains of the receptor sequences. Most of these probes $(\mathrm{m} 1,3,4,5)$ are identical to those previously characterized by others using Northern blot analysis (Bonner et al., 1987; Buckley et al., 1988). The $\mathrm{m} 2$ probe was complementary to bases $4-51$ of the sequence reported by Gocayne et al. (1987). All probes were characterized on sections of other autonomic targets as well as on sections of rat brain (M. P. Grant and S. C. Landis, unpublished observations) and yield distributions similar to those reported previously (Peralta et al., 1987a; Buckley et al., 1988; Maeda et al., 1988). Taken together, these studies indicate that each probe recognizes a unique receptor mRNA. For in situ hybridization histochemistry, all probes were labeled on the $3^{\prime}$ end using terminal deoxynucleotidyl transferase (Bethesda Research Labs) and ${ }^{35} \mathrm{~S}$-deoxyadenosine $5^{\prime}$-[ $\alpha$-thio]triphosphate as previously described (Young et al., 1986). 

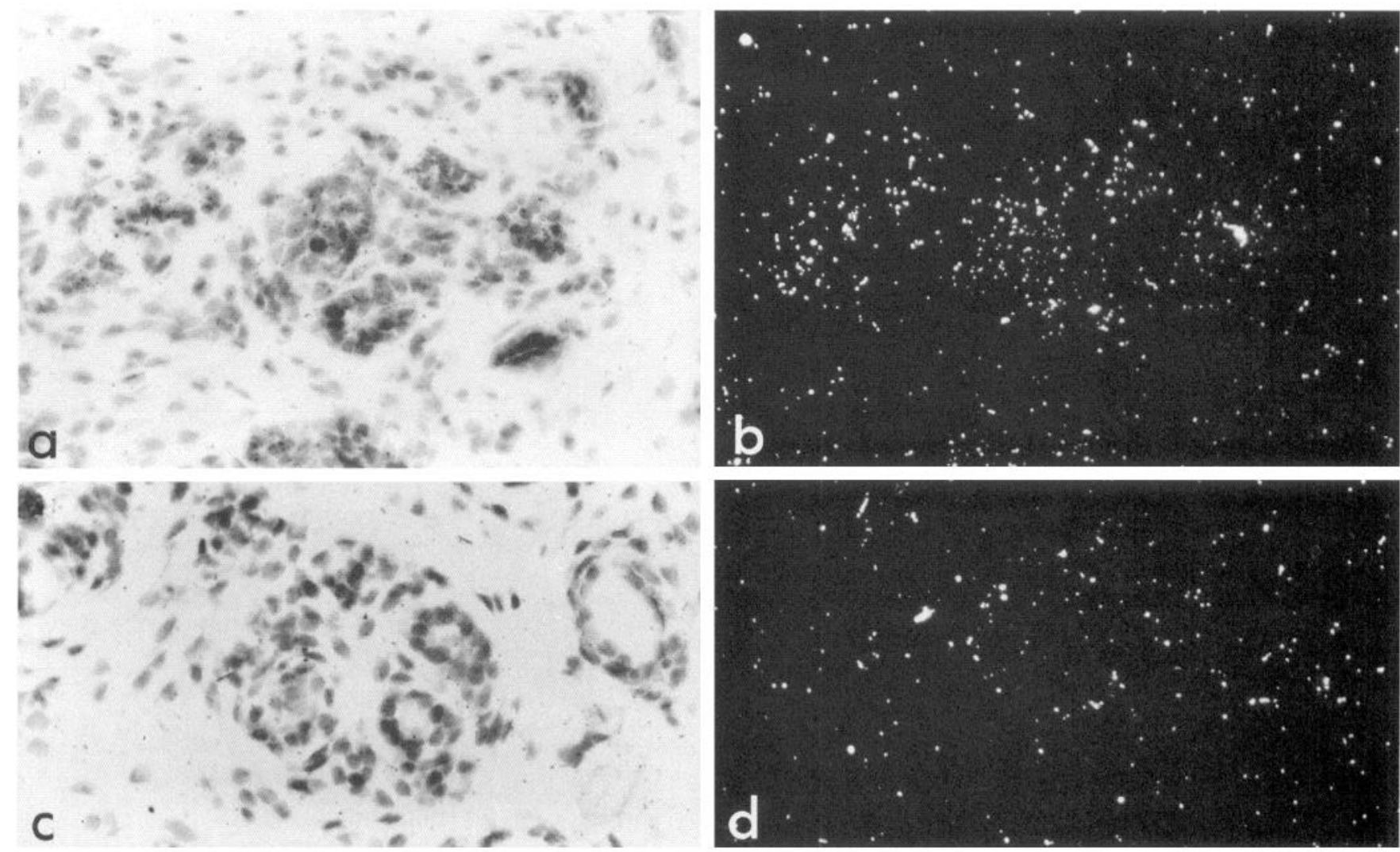

Figure 4. In situ hybridization of sections of adult rat sweat gland with the $\mathrm{m} 3$ - and $\mathrm{m} 1$-specific ${ }^{35} \mathrm{~S}$-labeled oligonucleotide probes. Ten-micron frozen sections were cut and processed with the appropriate oligonucleotide probe. Bright-field ( $a$ and $c$ ) and corresponding dark-field $(b$ and $d$ ) views of sections of adult rat sweat gland secretory coils hybridized with the $\mathrm{m} 3$ and $\mathrm{m} 1{ }^{35} \mathrm{~S}$-labeled oligonucleotide probe are shown. Message for the $\mathrm{m} 3(a$ and $b$ ) receptor subtype was evident in cells of the secretory coil, while message for the m1 muscarinic receptor subtype was not ( $c$ and d). Autoradiograms were exposed for 6 weeks. Magnification, $315 \times$.

\section{Results}

Characterization of muscarinic receptors in sweat glands

To determine the concentration $\left(B_{\max }\right)$ and dissociation constant $\left(K_{d}\right)$ of the muscarinic cholinergic receptor in rat sweat glands, homogenates of gland-rich tissue were incubated with concentrations of $\left[{ }^{3} \mathrm{H}\right] \mathrm{NMS}$ ranging from 0.025 to $1.25 \mathrm{nM}$. The muscarinic binding sites were saturated between 0.8 and $1.2 \mathrm{~nm}$ $\left[{ }^{3} \mathrm{H}\right]$ NMS. Scatchard analysis of these data revealed that the concentration of muscarinic receptors was $301 \mathrm{fmol} / \mathrm{mg}$ membrane protein and the $K_{d}$ was 131 pM (Fig. 1). Competition studies with well-characterized muscarinic antagonists and agonists demonstrated a typical muscarinic cholinergic pharmacology (Fig. 2a). Atropine blocked [ $\left.{ }^{3} \mathrm{H}\right] \mathrm{NMS}$ binding with high affinity, oxotremorine sesquifumarate and pilocarpine inhibited $\left[{ }^{3} \mathrm{H}\right] \mathrm{NMS}$ binding with intermediate affinity, and carbamylcholine inhibited $\left[{ }^{3} \mathrm{H}\right] \mathrm{NMS}$ binding with low affinity. Competition studies were also performed with selective muscarinic antagonists (Fig. $2 b$ ). In our assay system, 4-DAMP inhibited $\left[{ }^{3} \mathrm{H}\right] \mathrm{NMS}$ binding with high affinity. Pirenzepine inhibited $\left[{ }^{3} \mathrm{H}\right] \mathrm{NMS}$ binding with intermediate affinity in homogenates of gland-rich tissue. The putative $M_{2}$ heart-specific analog of pirenzepine, AF DX-116, bound to muscarinic binding sites in gland-rich tissue with low affinity.

Since the tissue used for the muscarinic binding assays was heterogeneous and contained fat cells and blood vessels as well as sweat glands, receptor autoradiography was performed to localize $\left[{ }^{3} \mathrm{H}\right] \mathrm{NMS}$ binding sites in footpads. Grains representing specific binding were concentrated over the secretory coil and were absent from blood vessels and the surrounding connective tissue (Fig. 3). The density of grains associated with the secretory duct appeared lower than that associated with the secretory coil; however, since relatively few sections contained secretory duct, this difference was not examined quantitatively. Ligand binding sites appeared to be uniformly distributed over the secretory coil. Basbaum et al. (1984) have reported that ligand binding sites in both tracheal serous and mucous glands are primarily associated with the basolateral surface. The autoradiographic method used in the present studies, however, did not possess sufficient resolution to reveal such a distribution pattern in rat sweat glands or to distinguish binding to secretory cells or myoepithelial cells within the coil or to possible presynaptic receptors in the gland innervation. Thus, sweat glands were the only structure with significant levels of muscarinic binding sites in the footpad, and these sites are expressed in the glands themselves.

In situ hybridization histochemistry performed on sections of adult rat footpad demonstrated the presence of mRNA encoding the $\mathrm{m} 3$ molecular subtype of the muscarinic receptor (Fig. $4 a, b)$. Sections of rat footpad were screened with oligonucleotide probes selective for each of the five molecular subtypes. Following hybridization, only the $\mathrm{m} 3 \mathrm{mRNA}$ was detectable. While message for the $\mathrm{ml}$, as well as the $\mathrm{m} 3$, receptor subtype has been described in porcine parotid gland, we found no evidence for 

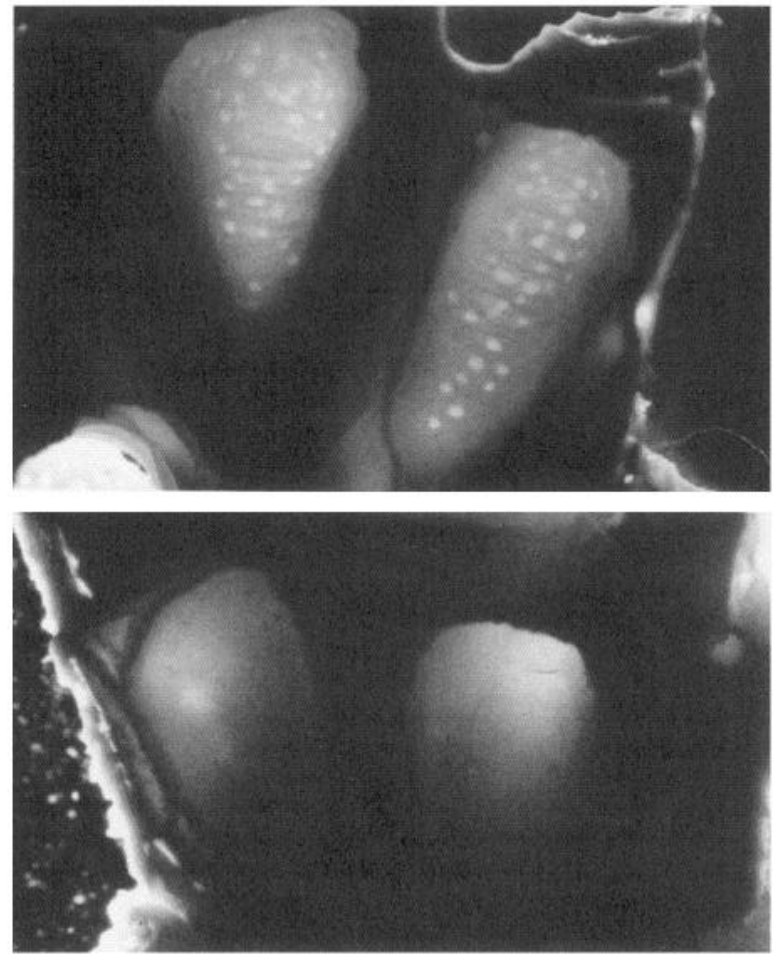

Figure 5. Sweating response in an adult rat with a unilateral lesion of the sciatic nerve. The animal was given a subcutaneous injection of the pilocarpine $(3 \mathrm{mg} / \mathrm{kg})$, and secretion was assayed $20 \mathrm{~min}$ postinjection. $a$, The glands in the control footpad respond robustly to the pilocarpine challange. Each pore, which appears as a white spot, represents the activity of a single gland. $b$, The glands in the denervated footpad did not respond to the muscarinic agonist. Magnification, $15 \times$.

the expression of $\mathrm{ml}$ mRNA in rat sweat gland (Figure $4 c, d$ ) even though our $\mathrm{ml}$ probe exhibited the expected distribution on sections of rat brain (data not shown).

\section{Effects of denervation on muscarinic receptor expression}

To investigate the possible effects of denervation on the expression of muscarinic cholinergic receptors, we determined the concentration and $K_{d}$ of muscarinic receptors in homogenates of gland-rich tissue isolated from acutely denervated adult animals. Sweat glands were denervated by sectioning the sciatic nerve $7 \mathrm{~d}$ prior to assay. Previous studies have demonstrated that following denervation rat and mouse sweat glands do not sweat in response to local or systemic treatment with cholinergic agonists (Hayashi and Nakagawa, 1963; Kennedy and Sakuta, 1984), and we found that sensitivity to cholinergic agonists was absent $7 \mathrm{~d}$ following sciatic nerve lesion (Fig. 5). Homogenates of control and denervated gland-rich tissue were incubated with concentrations of $\left[{ }^{3} \mathrm{H}\right] \mathrm{NMS}$ ranging from 0.025 to $1.2 \mathrm{nM}$, and binding data were analyzed by the method of Scatchard. The concentration of muscarinic binding sites was $239 \mathrm{fmol} / \mathrm{mg}$ membrane protein, and the $K_{d}$ was 219 pM (Fig. 6). These values are not significantly different from those obtained for the concentration and $K_{d}$ for muscarinic receptors in footpads on the contralateral unoperated side $(271 \mathrm{fmol} / \mathrm{mg}$ protein and $181 \mathrm{pM}$, respectively; $p>0.05$ ).

The distribution and molecular subtype of muscarinic binding sites in denervated sweat glands were similar to those of control glands (Fig. 7). Quantitative analysis of receptor autoradiogra-

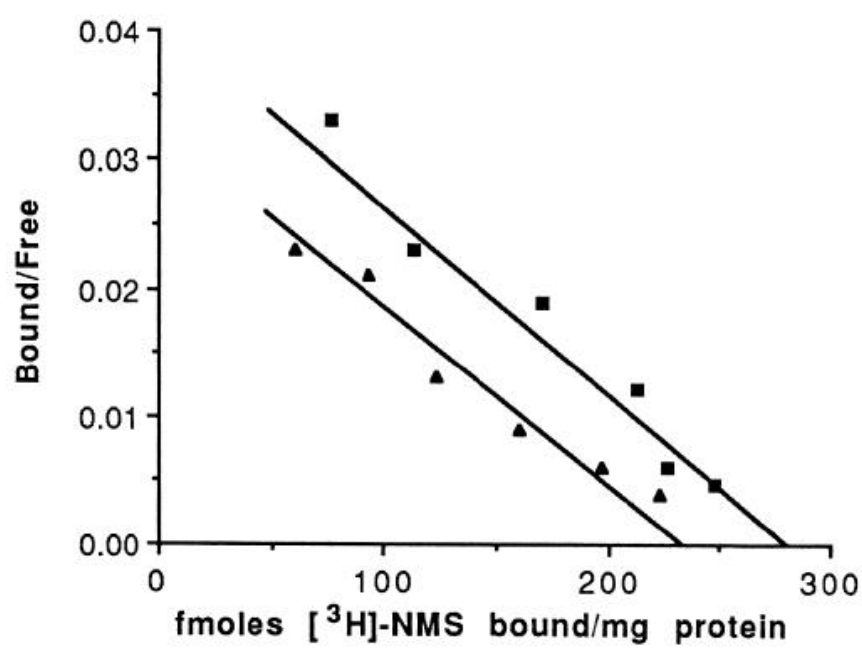

Figure 6. Equilibrium binding of $\left[{ }^{3} \mathrm{H}\right] \mathrm{NMS}$ to homogenates of denervated rat footpad. Homogenates of rat footpad isolated from control and denervated adult rats were incubated with increasing concentrations of $\left[{ }^{3} \mathrm{H}\right] \mathrm{NMS}$, and the binding data were analyzed by the Scatchard method. The data shown are representative of results obtained in four separate experiments, and each point is the mean of three determinations. Triangles represent denervated tissue; squares represent controls. The calculated $K_{d}$ and $B_{\max }$ for this experiment were $177 \pm 12$ pM and $282 \pm 22 \mathrm{fmol} / \mathrm{mg}$ protein, respectively, for control and $197 \pm 16 \mathrm{pM}$ and $242 \pm 20 \mathrm{fmol} / \mathrm{mg}$ protein for denervated tissue. Following EBDA LIGAND analysis, the $K_{d}$ and $B_{\max }$ of the receptor were determined to be $181 \pm 10 \mathrm{pm}$ and $271 \pm 25 \mathrm{fmol} / \mathrm{mg}$ protein, respectively, for the control and $219 \pm 9 \mathrm{pM}$ and $239.0 \pm 27 \mathrm{fmol} / \mathrm{mg}$ protein for the denervated tissues. These changes were not statistically significant $(n=4 ; p>0.05)$.

phy indicated that the grain density over denervated glands was not significantly different than over control glands. In situ hybridization studies demonstrated that, as in control glands, only mRNA encoding the $m 3$ receptor subtype was detectable in denervated glands. Furthermore, both expressed similar levels of this mRNA; the density of grains over denervated glands when compared to control glands was unchanged as well.

\section{Discussion}

In these studies we have characterized the properties of muscarinic receptors in adult rat sweat glands and examined the effects of denervation on muscarinic receptor expression, a treatment that causes loss of functional responsiveness in the glands. The muscarinic cholinergic receptor expressed by the glands is the $\mathrm{M}_{2}$ glandular receptor, and both the affinity and concentration of these sites are comparable to those described for other peripheral tissues. This pharmacologically defined receptor subtype corresponds to the $\mathrm{m} 3$ molecular subtype. Denervation of adult rat sweat glands did not significantly change either the concentration or the affinity of muscarinic receptors, nor did it detectably alter the molecular subtype expressed. Receptor autoradiography revealed that the distribution and concentration of specific grains were unchanged as well. Thus, cholinergic innervation does not regulate the functional responsiveness of rat sweat glands at the level of receptor expression.

The pharmacological properties of the muscarinic binding site in rat sweat glands as determined with the nonselective muscarinic antagonist $\left[{ }^{3} \mathrm{H}\right] \mathrm{NMS}$ are consistent with those described in previous studies of other peripheral autonomic target tissues (Dehaye et al., 1984; Siegel and Fischbach, 1984; Waelbroeck et al., 1986, 1987). Analysis of saturation curves suggested that 

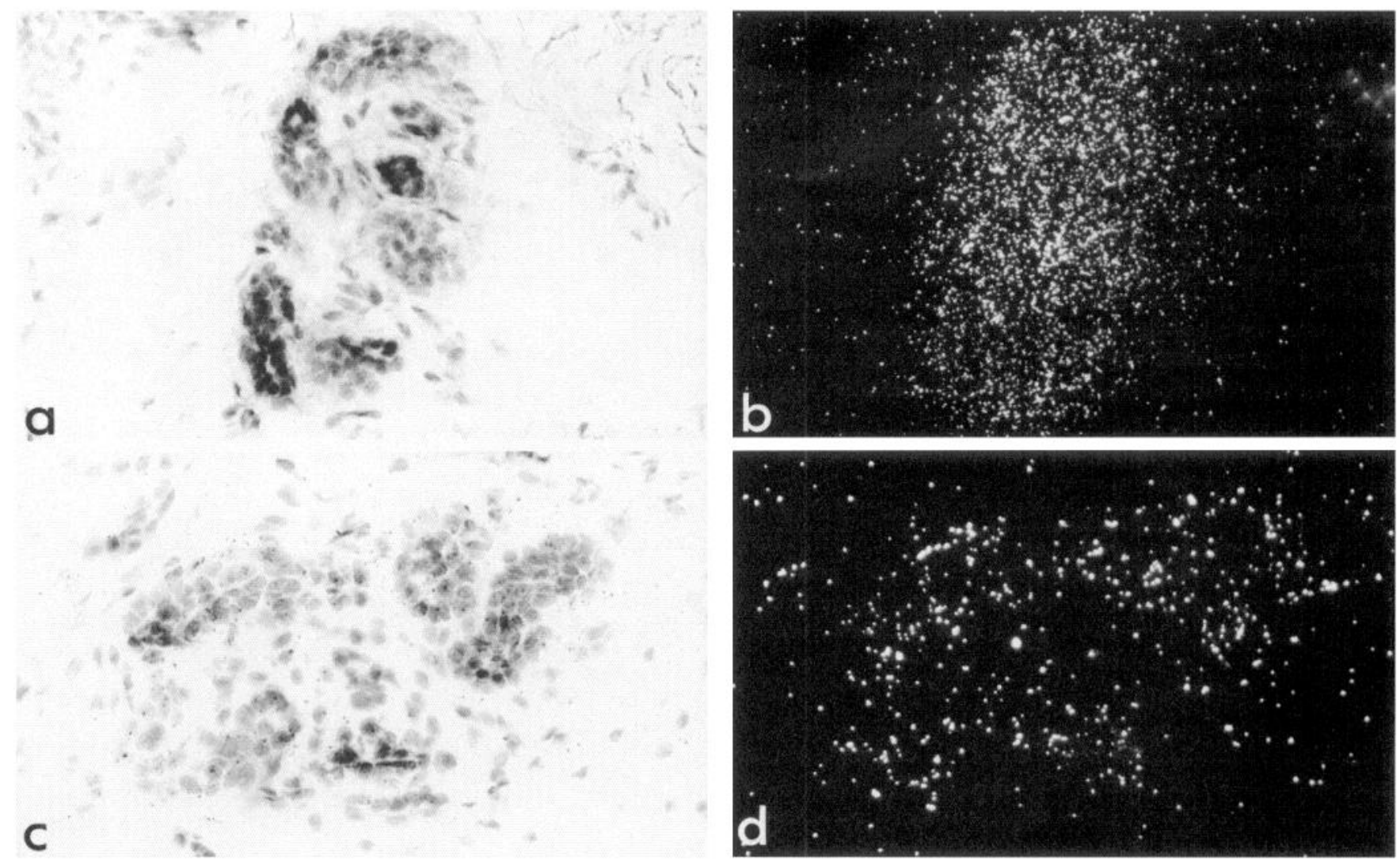

Figure 7. Autoradiograms of $\left[{ }^{3} \mathrm{H}\right] \mathrm{NMS}$ binding and in situ hybridization with $\mathrm{m} 3$-specific oligonucleotide probe to sections of acutely denervated footpads from adult rats. Footpads of adult rats were denervated by sectioning the sciatic nerve and examined $7 \mathrm{~d}$ later for the presence of muscarinic binding sites and $\mathrm{m} 3 \mathrm{mRNA}$. Ten-micron sections of footpad were incubated with $1 \mathrm{nM}\left[{ }^{3} \mathrm{H}\right] \mathrm{NMS}$ or hybridized with the m3 probe and processed for autoradiography. Secretory coils of denervated rat sweat glands are shown in bright-field $(a$ and $c)$. Specific grains corresponding to [ $\left.{ }^{3} \mathrm{H}\right] \mathrm{NMS}$ receptor binding sites $(b)$ or to $\mathrm{m} 3$ receptor mRNA $(d)$ are evident over the coils when they are examined with dark-field. The density of specific grains was not significantly different for receptor autoradiography $(93 \pm 7 \%$ of control) or in situ hybridization ( $103 \pm 9 \%$ of control). Receptor autoradiograms were exposed for 12 weeks, and in situ hybridization autoradiograms were exposed for 6 weeks. Magnification, $315 \times$.

$\left[{ }^{3} \mathrm{H}\right] N M S$ bound to a single site with high affinity. Competition studies with well-characterized muscarinic ligands produced the following order of potency: atropine $>$ oxotremorine $>$ pilocarpine $>$ carbachol. This order of potency is consistent with previous studies of other peripheral muscarinic receptors (Hootman and Ernst, 1981; Dehaye et al., 1984). Using selective muscarinic antagonists, we determined that the muscarinic site exhibited high affinity for 4-DAMP, intermediate affinity for pirenzepine, and low affinity for AF DX-116. Based on our studies and the studies cited above, the muscarinic receptor expressed in rat sweat glands can be defined pharmacologically as an $\mathbf{M}_{2}$ glandular muscarinic receptor.

It is not clear, however, that receptors defined pharmacologically in each tissue type as $\mathbf{M}_{2}$ glandular all correspond to the same unique molecular subtype (see Hootman et al., 1985). Using oligonucleotide probes specific for each of the five muscarinic receptor molecular subtypes, we have determined that mRNA encoding the $\mathrm{m} 3$ receptor subtype is present in adult rat sweat glands. Message for the other muscarinic receptor subtypes was not detected. Expression studies utilizing cell lines transfected with muscarinic receptor $\mathrm{cDNAs}$ have suggested that the muscarinic receptor encoded by the $\mathrm{m} 3$ gene displays a pharmacological profile attributed to the $\mathbf{M}_{2}$ glandular pharmacological subtype (Peralta et al., 1987a; Akiba et al., 1988; Bonner et al., 1988). Accordingly, one would predict that the receptor encoded by the $m 3$ gene corresponds to the $M_{2}$ glandular receptor; whether the pharmacological properties determined in cell line expression studies necessarily correspond to those of the native receptors in vivo has not yet been examined in detail. Our results provide support for this identification since sweat glands express detectable levels of only the $\mathrm{m} 3$ message and the pharmacological properties of the sweat gland receptor are characteristic of the $\mathrm{M}_{2}$ glandular subtype.

Cholinergic denervation produced little change in the distribution or pharmacological properties of muscarinic receptors expressed by rat sweat glands. Interestingly, 3-5 d after sciatic nerve lesion, the glands no longer respond to administration of cholinergic agonists despite the presence of a normal complement of muscarinic binding sites. A similar discrepancy between the presence of muscarinic binding sites and cholinergic sensitivity has been described in cultured chick myocytes (Siegel and Fischbach, 1984). Furthermore, the affinity of the muscarinic site was unchanged following denervation, and the saturation curve was not fit significantly better by a two-site model; these observations suggest that a new class of receptors was not expressed following denervation. In other studies, denervation of other peripheral autonomic targets resulted in increases, decreases, or no change in the concentration of muscarinic receptors (Sachs et al., 1979; Talamo et al., 1979; Nilvebrant et al., 1986). In rat parotid gland, the most similar to sweat glands of 
the tissues examined, muscarinic receptor concentration was reduced slightly following denervation; the gland, however, became supersensitive to muscarinic stimulation (Talamo et al., 1979; Ekstrom, 1980). Thus, innervation may have similar effects on the expression of muscarinic receptors in both parotid and sweat glands; however, innervation clearly regulates postreceptor coupling to secretion in a very different manner.

The signal transduction pathway regulating secretion in the rat sweat gland has not yet been fully elucidated. Thus far, sweat secretion in rats has been shown to be calcium dependent and consist of a high potassium and chloride effluent (Sato and Sato, 1978). Studies performed on other exocrine gland cells, principally lacrimal cells, suggest that secretion is stimulated via the PI pathway. In lacrimal cells the generation of inositol triphosphate promotes the release of intracellular $\mathrm{Ca}^{2+}$, which activates potassium and chloride ion channels (Trautman and Marty, 1984; Evans and Marty, 1986; reviewed by Marty, 1987). In addition, the coupling of muscarinic receptors to secretion has been extensively investigated in the parotid gland, where it is also thought to be regulated through the PI pathway (Haddas et al., 1979; Aub et al., 1982). It seems likely that a similar mechanism occurs in rat sweat glands, where the $\mathrm{m} 3$ molecular subtype, which has been shown previously to be preferentially coupled to PI turnover, is expressed (Fukuda et al., 1988; Peralta et al., 1988).

Clearly, there are several points in the signal transduction/ secretory pathway at which cholinergic innervation could control responsiveness. One possibility is that innervation regulates the expression of the appropriate muscarinic receptor subtype. This is analogous to the reexpression of the $\gamma$-subunit of the skeletal muscle nicotinic ACh receptor that occurs following the denervation (Moss et al., 1987; Witzemann et al., 1987; Gu and Hall, 1988). However, our finding that the molecular subtype of muscarinic receptor and the levels of mRNA remain unchanged following denervation makes this unlikely. An alternative explanation is that the appropriate receptor is present but exists in a nonfunctional state. This phenomenon has been described for the neuronal nicotinic $\mathrm{ACh}$ receptor in chick ciliary ganglion; in these cells, agents that increase intracellular levels of cAMP induce increases in the number of functional receptors, possibly by phosphorylating the receptor or an associated regulatory protein (Margiotta et al., 1987; reviewed by Berg et al., 1989). While a precedent for this type of regulation does not exist for G-protein-coupled receptors, phosphorylation has been suggested to play a role in agonist-mediated downregulation of $\beta$-adrenergic receptors (Benovic et al., 1986).

Another explanation for functional nonresponsiveness is that a functional receptor is present but uncoupled from the secretory pathway. This could occur either through the absence or downregulation of the appropriate G-protein(s) or at a point distal to the G-protein. Both of these mechanisms have been observed in embryonic and early postnatal chick hearts. In this tissue the onset of muscarinic cholinergic-mediated inhibition of adenyl cyclase is correlated with the appearance of the $39 \mathrm{kDa}$ G-protein $\alpha$-subunit (Halvorson and Nathanson, 1984; Liang et al., 1986). In the same experimental system, however, a step distal to the G-protein can also be downregulated (Hunter and Nathanson, 1984, 1986). Our results suggest that the latter type of regulation also occurs in rat sweat glands, where G-protein coupling is unaffected by denervation (Grant and Landis, 1991). Identification of the step or steps compromised by denervation will provide valuable insight into the mechanisms by which innervation can regulate responsiveness in autonomic target tissues.

\section{References}

Akiba I, Kubo T, Maeda A, Bujo H, Nakai J, Mishina M, Numa S (1988) Primary structure of porcine muscarinic acetylcholine receptor III and antagonist binding studies. FEBS Lett 235:257-261.

Ashkenazi A, Winslow JW, Peralta EG, Peterson GL, Schimerlik MI, Capon DJ, Ramachandran J (1987) An $\mathbf{M}_{2}$ muscarinic receptor subtype coupled to both adenyl cyclase and phosphoinositide turnover. Science 238:672-675.

Aub DL, McKinney JS, Putney JW (1982) Nature of the receptor regulated calcium pool in the rat parotid gland. J Physiol (Lond) 331: 557-565.

Barlow RB, Shepherd MK (1986) A further search for selective antagonists at $\mathbf{M}_{2}$ muscarinic receptors. Br J Pharmacol 89:837-843.

Bashaum CB, Grillo MA, Widdicombe JH (1984) Muscarinic receptors: evidence for a nonuniform distribution in tracheal smooth muscle and exocrine glands. J Neurosci 4:508-520.

Benovic JL, Strasser RH, Caron MG, Lefkowitz RJ (1986) Beta-adrenergic receptor kinase: identification of a novel protein kinase that phosphorylates the agonist-occupied form of the receptor. Proc Natl Acad Sci USA 83:2797-2801.

Berg DK, Boyd RT, Halvorson SW, Higgins LS, Jacob MH, Margiotta JS (1989) Regulating the number and function of neuronal acetylcholine receptors. Trends Neurosci 12:16-20.

Bonner TI (1989) The molecular basis of muscarinic receptor diversity. Trends Neurosci 12:148-152.

Bonner TI, Buckley NJ, Young A, Brann MR (1987) Identification of a family of muscarinic receptor genes. Science 237:527-532.

Bonner TI, Young AC, Brann MR, Buckley NJ (1988) Cloning and expression of the human and rat $\mathrm{m} 5$ muscarinic acetylcholine receptor genes. Neuron 1:403-410.

Buckley NJ, Bonner TI, Brann MR (1988) Localization of a family of muscarinic receptor mRNAs in rat brain. J Neurosci 8:4646-4652.

Buckley NJ, Bonner TI, Buckley CM, Brann MR (1989) Antagonist binding properties of five cloned muscarinic receptors expressed in CHO-K1 cells. Mol Pharmacol 35:469-476.

Dehaye JP, Winard J, Poloczek P, Christophe J (1984) Characterization of muscarinic cholinergic receptors on rat pancreatic acini by $N-\left[{ }^{3} \mathrm{H}\right]$-methylscopolamine binding. J Biol Chem 259:294-300.

Ekstrom J (1980) Sensitization of the rat parotid gland to secretagogues following either parasympathetic denervation or sympathetic denervation or decentralization. Acta Physiol Scand 108:253-261.

Evans MG, Marty A (1986) Calcium-dependent chloride currents in isolated cells from rat lacrimal glands. J Physiol (Lond) 378:437-460.

Fukuda K, Higashida H, Kubo T, Maeda A, Akiba I, Bujo H, Mishina M, Numa S (1988) Sclective coupling with $\mathrm{K}^{+}$currents of muscarinic acetylcholine receptor subtypes in NG108-15 cells. Nature 335:355358.

Gocayne J, Robinson DA, FitzGerald MG, Chung F, Kerlavage R, Lentes K, Lai J, Wang C, Fraser CM, Venter JC (1987) Primary structure of rat cardiac $\beta$-adrenergic and muscarinic cholinergic receptors obtained by automated DNA sequence analysis: further evidence for a multigene family. Proc Natl Acad Sci USA 84:82968300.

Grant MP, Landis SC (1988) Expression of muscarinic cholinergic receptors on rat sweat glands. Soc Neurosci Abstr 14:429.

Grant MP, Landis SC (1989) Nerve-target interactions in the developing sympathetic nervous system: development of an $\mathrm{m} 3$ muscarinic receptor. Soc Neurosci Abstr 15:1329.

Grant MP, Landis SC (1991) Developmental expression of muscarinic cholinergic receptors and coupling to phospholipase $\mathrm{C}$ on rat sweat glands are independent of innervation. J Neurosci 11:3772-3782.

Gu Y, Hall ZW (1988) Immunological evidence for a change in subunits of the acetylcholine receptor in developing and denervated rat muscle. Neuron 1:117-125.

Haddas RA, Landis CA, Putney JW (1979) Relationship between calcium release and potassium release in rat parotid gland. $J$ Physiol (Lond) 291:457-465.

Halvorson SW, Nathanson NM (1984) Ontogenesis of physiological responsiveness and guanine nucleotide sensitivity of cardiac muscarinic receptors during chick embryonic development. Biochemistry 23:5813-5821. 
Hammer R, Berrie CP, Birdsall NJM, Burgen ASV, Hulme EC (1980) Pirenzepine distinguishes between different subclasses of muscarinic receptor. Nature 283:90-92.

Hammer R, Giraldo E, Schiavi GB, Montefereni E, Laninsky H (1986) Binding profile of a novel cardioselective muscarinic rcceptor antagonist, AF-DX 116, to membranes of peripheral tissues and brain in the rat. Life Sci 38:1653-1662.

Hayashi H, Nakagawa T (1963) Functional activity of the sweat glands of the albino rat. J Invest Dermatol 41:365-367.

Herkenham MA (1985) Autoradiographic methods for receptor localization. In: Society for Neurosciences 15 th annual meeting, Short course 1 syllabus, pp 44-60.

Hootman SR, Ernst SA (1981) Characterization of muscarinic acetylcholine receptors in the avian salt gland. J Cell Biol 91:781-789.

Hootman SR, Piado-Leonard TM, Burham DB (1985) Muscarinic acetylcholine receptor structure in acinar cells of mammalian exocrine glands. J Biol Chem 260:4186-4194.

Hulme EC, Birdsall NJM, Buckley NJ (1990) Muscarinic receptor subtypes. Annu Rev Pharmacol Toxicol 30:633-673.

Hunter DD, Nathanson NM (1984) Decreased physiological sensitivity mediated by newly synthesized muscarinic acetylcholine receptors in embryonic chick heart. Proc Natl Acad Sci USA 81:3582-3586.

Hunter DD, Nathanson NM (1986) Biochemical and physiological analyses of newly synthesized muscarinic acetylcholine receptors in cultured embryonic chicken cardiac cells. J Neurosci 6:3739-3748.

Jones SV, Barker JR, Buckley NJ, Bonner TI, Collins RM, Brann MR (1988) Cloned muscarinic receptor subtypes expressed in A9 cells differ in their coupling to electrical responses. Mol Pharmacol 34 $421-426$.

Kennedy WR, Sakuta M (1984) Collateral reinnervation of sweat glands. Ann Neurol 15:73-78.

Kennedy WR, Sakuta M, Quick DC (1984) Rodent eccrine sweat glands: a case of multiple efferent innvervation. Neuroscience 11:741749.

Kubo T, Fukuda K, Mikami A, Maeda A, Takahashi H, Mishina M, Haga K, Ichiyama A, Kangawa K, Kojima M, Matsuo H, Hilrose T, Numa S (1986a) Cloning, sequencing and expression of complementary DNA encoding the muscarinic acetylcholine receptor. Nature 323:411-416.

Kubo T, Maeda A, Sugimoto K, Akiba I, Mikami A, Takahashi H, Haga T, Haga K, Ichiyama A, Kangawa $K$, Matsuo $H$, Mishina $M$ Hilrose T, Numa S (1986b) Primary structure of porcine cardiac muscarinic acetylcholine receptor deduced from the cDNA sequence. FEBS Lett 209:367-372.

Landis SC, Keefe D (1983) Evidence for neurotransmitter plasticity in vivo: developmental changes in properties of cholinergic sympathetic neurons. Dev Biol 98:349-372.

Leblanc G, Landis SC (1986) Development of choline acetyltransferase (CAT) in sympathetic innervation of rat sweat glands. J Neurosci 6:260-265

Liang BT, Hellmich HR, Neer EJ, Galper JB (1986) Development of muscarinic cholinergic inhibition of adenylate cyclase in embryonic chick heart. J Biol Chem 261:901 1-9021.

Lowry OW, Rosebrough NJ, Farr AJ, Randell RJ (1951) Protein measurement with Folin phenol reagent. J Biol Chem 193:256-275.

Maeda A, Kubo T, Mishina M, Numa S (1988) Tissue distribution of mRNAs encoding muscarinic acetylcholine receptor subtypes. FEBS Lett 239:339-342.

Margiotta JF, Berg DK, Dionne V (1987) Cyclic AMP regulates the proportion of functional acetylcholine receptors on chick ciliary ganglion neurons. Proc Natl Acad Sci USA 84:8155-8159.

Marty A (1987) Control of ionic currents and fluid secretion by muscarinic agonists in exocrine glands. Trends Neurosci 10:373-377.
Moss SJ, Beeson DMW, Jackson JF, Darlison MG, Barnard EA (1987) Differential expression of nicotinic acetylcholine receptor genes in innervated and denervated chicken muscle. EMBO J 6:3917-3921.

Nathanson NM (1987) Molecular properties of the muscarinic acetylcholine receptor. Annu Rev Neurosci 10:195-236.

Nilvebrant L, Ekstrom J, Malmberg L (1986) Muscarinic receptor density in the rat urinary bladder after denervation, hypertrophy and urinary diversion. Acta Pharmacol Toxicol (Copenh) 59:306-314.

Peralta EG, Ashkenazi A, Winslow JW, Smith DH, Ramachandran J, Capon DJ (1987a) Distinct primary structures, ligand-binding properties and tissue specific expression of four human muscarinic acetylcholine receptors. EMBO J 6:3923-3929.

Peralta EG, Winslow JW, Peterson GL, Smith DH, Ashkenazi A, Ramachandran J, Schimerlick MI, Capon DJ (1987b) Primary structure and biochemical properties of an $\mathbf{M}_{2}$ muscarinic receptor. Science 236:600-605.

Peralta EG, Ashkenazi A, Winslow JW, Ramachandran J, Capon DJ (1988) Differential regulation of PI hydrolysis and adenylyl cyclase by muscarinic receptor subtypes. Nature 344:434-437.

Sachs DI, Kloog Y, Korczyn AD, Heron DS, Sokolovsky M (1979) Denervation, supersensitivity and muscarinic receptors in the cat iris. Biochem Pharmacol 28:1513-1518.

Sato F, Sato K (1978) Secretion of a potassium-rich fluid by the secretory coil of the rat paw eccrine sweat gland. J Physiol (Lond) 274: $37-50$.

Scatchard G (1949) The attraction of proteins for small molecules and ions. Ann NY Acad Sci 51:660-672.

Siegel RE (1988) The mRNAs encoding GABA $\mathrm{A}_{\mathrm{A}}$ /benzodiazepine receptor subunits are localized in different cell populations of the bovine cerebellum. Neuron 1:579-584.

Siegel RE, Fischbach GD (1984) Muscarinic receptors and responses in intact embryonic chick atrial and ventricular heart cells. Dev Biol 101:346-356

Stevens LM, Landis SC (1987) Development and properties of the secretory response in rat sweat glands: relationship to the induction of cholinergic function in sweat gland innervation. Dev Biol 123:179190.

Talamo BR, Adler SC, Burt DR (1979) Parasympathetic denervation decreases muscarinic receptor binding in rat parotid. Life Sci 24: $1573-1580$

Trautman A, Marty A (1984) Activation of calcium-dependent potassium channels by carbamylcholine in rat lacrimal glands. Proc Natl Acad Sci USA 81:611-615.

Waelbroeck M, Gillard M, Robbercht P, Christophe J (1986) Kinetic studies of $\left[{ }^{3} \mathrm{H}\right]-N$-methylscopolamine binding to muscarinic receptors in the rat central nervous system: evidence for the existence of three classes of binding sites. Mol Pharmacol 30:305-314.

Waelbroeck M, Gillard M, Robbercht P, Christophe J (1987) Muscarinic receptor heterogeneity in rat central nervous system. I. Binding of four selective antagonists to three muscarinic receptor subclasses: a comparison with $\mathbf{M}_{2}$ cardiac muscarinic receptors of the $\mathrm{C}$ type. Mol Pharmacol 32:91-99.

Wamsley JK, Lewis MS, Young WS III, Kuhar MJ (1981) Autoradiographic localization of muscarinic cholinergic receptors in rat brainstem. J Neurosci 1:176-191.

Witzemann V, Barg B, Nishikawa Y, Sakmann B, Numa S (1987) Differential regulation of muscle acetylcholine receptor gamma and epsilon-subunit mRNAs. FEBS Lett 223:104-112.

Young WS, Mezey E, Siegel RE (1986) Vasopressin and oxytocin mRNAs in adrenalectomized and Brattleboro rats: analysis by quantitative in situ hybridization histochemistry. Mol Brain Res 1:231241. 